\title{
Effect of replacing alfalfa with panicled-tick clover or sericea lespedeza in corn-alfalfa-based substrates on in vitro ruminal methane production
}

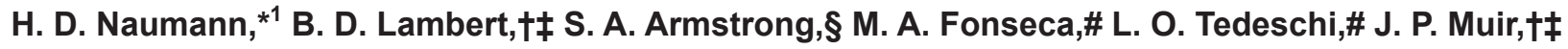 \\ and M. R. Ellersieckll \\ *Division of Plant Sciences, University of Missouri, Columbia 65211 \\ †Department of Wildlife, Sustainability, and Ecosystem Sciences, Tarleton State University, Stephenville, TX 76402 \\ ¥Texas A\&M AgriLife Research, Stephenville 76401 \\ §Oregon State University, Corvallis 97331 \\ \#Department of Animal Science, Texas A\&M University, College Station 77843 \\ IIDepartment of Statistics, University of Missouri, Columbia 65211
}

\begin{abstract}
Methane emissions from ruminant livestock contribute to total anthropogenic greenhouse gas emissions and reduce metabolizable energy intake by the animal. Condensed tannins (CT) are polyphenolic plant secondary compounds commonly produced by some perennial forage legumes that characteristically bind to protein, carbohydrates, and minerals. The degree to which CT may affect ruminant nutrition depends upon the concentration, structural composition, and biological activity of the CT. The objective of our experiment was to determine the effect of replacing alfalfa in a cornalfalfa-based substrate with a legume containing CT on in vitro $\mathrm{CH}_{4}$ production and the dynamics of fermentation using an in vitro gas production technique. All fermented substrates contained $50 \%$ ground corn as the energy concentrate portion, whereas the forage portion $(50 \%)$ of each diet was comprised of alfalfa (control) or some combination of alfalfa and sericea lespedeza (SL) or panicled-tick clover (PTC). Our treatments consisted of PTC or SL 15, 30, and 45, which corresponded with 15,30 , or $45 \%$ replacement of the diet (alfalfa component) with either PTC or SL. Substrates containing $45 \%$ PTC or SL reduced in vitro $\mathrm{CH}_{4}$ production. Treatments did not affect total gas production as compared with that of the control. Replacement of alfalfa with SL or PTC increased fermentable organic matter (FOM). The PTC treatment increased FOM by as much as $1.8 \%$ at the $45 \%$ replacement level, whereas FOM of SL 45 was increased by less than $1 \%$. The replacement of alfalfa with PTC increased substrate nutritive value greater than replacement with SL. There were no correlations between any physicochemi-
\end{abstract}

Received September 9, 2014.

Accepted March 1, 2015.

${ }^{1}$ Corresponding author: naumannhd@missouri.edu cal constituent of the substrates and $\mathrm{CH}_{4}$ production. A combination of factors associated with the inclusion of $\mathrm{PTC}$ and SL contributed to the in vitro $\mathrm{CH}_{4}$ production, and CT in these forages was likely a major contributing factor. Further confirmation of these results on in situ or in vivo animal systems is required. If proven effective in an in vivo production scenario, replacement of commonly fed non-CT-containing legumes, such as alfalfa, with legumes containing $\mathrm{CT}$ might be a viable method to decrease the effect of animal agriculture on greenhouse gas production.

Key words: condensed tannin, greenhouse gas, legume, ruminant

\section{INTRODUCTION}

Methane emissions from ruminant livestock contribute to total anthropogenic greenhouse gas emissions (Patra, 2012). Conventional ruminant feeding methods that incorporate large amounts of carbohydrates are often identified as factors contributing to further increases in greenhouse gas emissions. Enteric $\mathrm{CH}_{4}$ production is also a source of energy loss that can be attributed to inefficient digestion, primarily in the rumen of the ruminant animal (Johnson and Johnson, 1995), which results in a reduction of ME intake by the animal (Goel and Makkar, 2012). In intensive production systems, lactating dairy cattle are typically fed a diet consisting of approximately $50 \%$ concentrates and $50 \%$ roughage. Haylage produced from alfalfa (Medicago sativa L.), a forage legume containing no condensed tannin (CT), frequently comprises a substantial portion of the roughage present in these diets, whereas corn and corn byproducts are often used as energy concentrates.

Condensed tannins are polyphenolic plant secondary metabolites that demonstrate multiple biological activities in ruminants, including protein binding (Jones and Mangan, 1977), anthelmintic activity (Athanasiadou et al., 2001), and reduction in enteric $\mathrm{CH}_{4}$ emission 
(Grainger et al., 2009). Accurately determining CT concentration and biological activity in forages is difficult due to great diversity in their structural characteristics and reactivity (Schofield et al., 2001). A variety of methods can be used to estimate CT concentration and bioactivity, each having advantages and disadvantages. For example, the commonly used chemical assay, acid butanol method, which relies on the degradation of interflavan bonds to form anthocyanidin monomers and a subsequent color formation ranging from blue to red depending on the structural characteristics of the $\mathrm{CT}$, may often underestimate $\mathrm{CT}$ due to the presence of intractable interflavan bonds (Yokota et al., 2013). This method provides no indication of CT-macromolecule binding activity, so other methods must be used to estimate the concentration of biologically active CT (Hagerman and Butler, 1978; Asquith and Butler, 1985). Condensed tannin concentrations in birdsfoot trefoil have been reported to range from 1 to $3 \%$ when determined by acid butanol (Coblentz and Grabber, 2013). However, when the well-established proteinprecipitating assay of Hagerman and Butler (1978) was used in our laboratory to analyze the CT in birdsfoot trefoil, no protein binding ability was demonstrated $(\mathrm{H}$. D. Naumann, unpublished data). Our objective was to determine the effects of replacing alfalfa in a simulated dairy-type diet containing $50 \%$ corn grain with forage legumes varying in $\mathrm{CT}$ concentration on in vitro methane emission and total gas production.

\section{MATERIALS AND METHODS}

\section{Experimental Forages}

We evaluated plant material consisting of leaves from herbaceous warm-season perennial legumes, Desmodium paniculatum (L.) DC. var. paniculatum (panicled-tick clover; PTC) and Lespedeza cuneata (Dum. Cours.) G. Don (sericea lespedeza; SL), both known to contain CT that inhibit methane emissions (Animut et al., 2008a; Puchala et al., 2012; Naumann et al., 2013). Forage legumes were collected from multiple $4-\times 6$-m plots at Stephenville, Texas $\left(32^{\circ} 15^{\prime} \mathrm{N}, 98^{\circ} 12^{\prime} \mathrm{W}\right.$, altitude $=395$ $\mathrm{m})$ on a Windthorst sandy loam soil [Udic Paleustalf; $10 \mathrm{mg} / \mathrm{kg}$ of nitrate- $\mathrm{N}, 13 \mathrm{mg} / \mathrm{kg}$ of $\mathrm{P}, 206 \mathrm{mg} / \mathrm{kg}$ of K, $1416 \mathrm{mg} / \mathrm{kg}$ of $\mathrm{Ca}, 247 \mathrm{mg} / \mathrm{kg}$ of $\mathrm{Mg}, 15 \mathrm{mg} / \mathrm{kg}$ of S, $152 \mathrm{mg} / \mathrm{kg}$ of Na, $10.12 \mathrm{mg} / \mathrm{kg}$ of Fe, $0.59 \mathrm{mg} / \mathrm{kg}$ of Zn, $1.10 \mathrm{mg} / \mathrm{kg}$ of $\mathrm{Mn}$, and $0.22 \mathrm{mg} / \mathrm{kg}$ of Cu using Mehlich III extraction (Mehlich, 1984)]. Leaves were dried at $55^{\circ} \mathrm{C}$ in a forced-air oven for $48 \mathrm{~h}$, then ground to pass a 1-mm screen in a sheer mill (Arthur H. Thomas Co., Philadelphia, PA) and stored for subsequent chemical analysis.

\section{CT Purification, Quantification, and Characterization}

Purification. We extracted CT from plant tissue (25 g) with 70:30 (vol/vol) acetone:water. Acetone was removed by evaporation under reduced pressure and replaced by methanol. Condensed tannins were purified from each plant species using Sephadex LH-20 (GE Healthcare Bio-Sciences Corp., Piscataway, NJ; Strumeyer and Malin, 1975). The CT were released from the Sephadex by washing with 70:30 (vol/vol) acetone:water, and the purified CT were lyophilized. The purified CT from each individual species were used to develop species-specific standards for the acid butanol assays and for molecular weight determinations.

Quantification. We prepared plant extracts for each plant species by extracting $50 \mathrm{mg}$ of plant tissue with $1 \mathrm{~mL}$ of 50:50 (vol/vol) methanol:water on a rotator for $15 \mathrm{~min}$ followed by centrifugation at $16,000 \times$ $g$ for $5 \mathrm{~min}$ at $4^{\circ} \mathrm{C}$. We used the scaled-down protein precipitable phenolics method described by (Hagerman and Butler, 1978) to quantify biologically active CT (those that are readily extractable in the rumen environment and reactive with protein) in 3 replicate plant extracts. A $50-\mu \mathrm{L}$ aliquot of plant extract supernatant was combined with $250 \mu \mathrm{L}$ of Buffer A $(0.20 \mathrm{M}$ acetic acid, $0.17 \mathrm{M} \mathrm{NaCl}$ ), $50 \mu \mathrm{L}$ of BSA ( $5 \mathrm{mg} / \mathrm{mL}$ in Buffer A), and $50 \mu \mathrm{L}$ of 50:50 ( $\mathrm{vol} / \mathrm{vol}$ ) methanol:water and incubated at room temperature for 30 min before centrifuging at $16,000 \times g$ for $5 \mathrm{~min}$ at $4^{\circ} \mathrm{C}$. Supernatants were removed by vacuum aspiration and the proteinphenolic pellet was washed with $100 \mu \mathrm{L}$ of Buffer A before recentrifuging and aspirating. Protein-phenolic precipitates (PPP) were dissolved in $800 \mu \mathrm{L}$ of SDS $(1 \% \mathrm{wt} / \mathrm{vol})$-triethanolamine $(5 \% \mathrm{vol} / \mathrm{vol})$ before adding $200 \mu \mathrm{L}$ of $\mathrm{FeCl}_{3}\left(0.01 \mathrm{M} \mathrm{FeCl}_{3}\right.$ in $\left.0.01 \mathrm{M} \mathrm{HCl}\right)$. Absorbance at $510 \mathrm{~nm}$ was read after $15 \mathrm{~min}$ and PPP were quantified using standard curves prepared with stock solutions of CT extracts $(1 \mathrm{mg} / \mathrm{mL})$ in deionized water.

Characterization. We analyzed anthocyanidin monomer composition to determine the cyanidin-todelphinidin ratio of CT from PTC and SL under conditions similar to those described by Li et al. (2010). A solution of purified CT in acid butanol $(0.25 \mathrm{mg} / \mathrm{mL})$ was prepared for each plant species (PTC and SL) and allowed to react in a boiling water bath for $45 \mathrm{~min}$. Cyanidin and delphinidin analyses were conducted on the products of the acid butanol reaction using HPLC analysis (Waters Corporation, Milford, MA) controlled by Breeze Software (Waters Corporation). A 4.6- $\times$ 150-mm, 5- $\mu \mathrm{m}$ Waters Symmetry $\mathrm{C}_{18}$ column (Waters Corporation) was used. A 50- $\mu \mathrm{L}$ subsample of the acid butanol-reacted sample was injected prior to separa- 
Table 1. Substrate formulations ${ }^{1}$ (\%, DM basis)

\begin{tabular}{lcccc}
\hline Substrate $^{2}$ & Corn & Alfalfa & SL & PTC \\
\hline CRN:ALF & 50 & 50 & 0 & 0 \\
PTC 15 & 50 & 35 & 0 & 15 \\
PTC 30 & 50 & 20 & 0 & 30 \\
PTC 45 & 50 & 5 & 0 & 45 \\
SL 15 & 50 & 35 & 15 & 0 \\
SL 30 & 50 & 20 & 30 & 0 \\
SL 45 & 50 & 5 & 45 & 0 \\
\hline
\end{tabular}

${ }^{1} \mathrm{SL}=$ sericea lespedeza; PTC $=$ panicled-tick clover.

${ }^{2} \mathrm{CRN}: \mathrm{ALF}=$ corn-alfalfa control; PTC $15=15 \%$ panicled-tick clover; PTC $30=30 \%$ panicled-tick clover; PTC $45=45 \%$ panicled-tick clover; SL $15=15 \%$ sericea lespedeza; SL $30=30 \%$ sericea lespedeza; SL $45=45 \%$ sericea lespedeza.

tion. Separation was achieved using a gradient of $0.13 \%$ trifluoroacetic acid in $\mathrm{H}_{2} \mathrm{O}$ (mobile phase A) and $0.1 \%$ trifluoroacetic acid in acetonitrile (MeCN; mobile phase $\mathrm{B})$ at $0.5 \mathrm{~mL} / \mathrm{min}$ in a 45 -min program as follows: 0 to $10 \mathrm{~min}, 5 \% \mathrm{~B} ; 10$ to $15 \mathrm{~min}$, increase to $10 \% \mathrm{~B} ; 15$ to 20 min, increase to $20 \% \mathrm{~B} ; 20$ to $25 \mathrm{~min}, 20 \% \mathrm{~B} ; 25$ to $35 \mathrm{~min}$, increase to $55 \% \mathrm{~B}$; 35 to $40 \mathrm{~min}, 55 \% \mathrm{~B} ; 40$ to $45 \mathrm{~min}$, decrease to $5 \% \mathrm{~B}$. The eluate was analyzed at a wavelength of $550 \mathrm{~nm}$. Peaks were identified by comparing the retention time and spectra with those of commercially prepared cyanidin and delphinidin standards (Sigma-Aldrich Co., St. Louis, MO), and peak areas were calculated with Breeze Software (Waters Corporation).

\section{Experimental Substrates}

The formulation and nutritional qualities of the experimental substrates are shown in Tables 1 and 2, respectively. We chose a corn and alfalfa-based control substrate (CRN:ALF) because of the prevalence of those 2 ingredients in commonly fed dairy and beef cattle diets in high-intensity production systems. All substrates contained $50 \%$ ground corn as the energy concentrate portion. The forage portion $(50 \%)$ of each substrate was comprised of alfalfa (control) or some combination of alfalfa and SL or PTC (Table 1).

Cumberland Valley Analytical Services Inc. (Maugansville, MD) analyzed each component for concentrations of NDF, ADF, CP, ash, ether extract, lignin, ADIN, and NPN and reported results on a percent DM basis. We calculated fermentable organic matter (FOM) by subtracting ash, lignin, ether extract, ADIN, and NPN from 100.

\section{In Vitro Fermentation}

Each treatment was fermented in duplicate in each of 2 fermentation chambers in 2 separate fermentation events. Methane and total gas production were determined using an in vitro gas production technique, as described by Tedeschi et al. (2009). The animals used as rumen fluid donors were housed and cared for according to the guidelines of the Animal Care and Use Committee for the USDA-ARS Southern Plains Agricultural Research Center (FASS, 2010). For each replicate, 2 ruminally cannulated steers, unadapted to forage containing CT and fed bermudagrass (Cynodon dactylon L. Pers.) hay, were used for rumen fluid collection. Rumen fluid was collected concurrently from both steers and mixed at the time of collection. The same animals, consuming the same bermudagrass diet, were used for both fermentation events. With the exception of nonsubstrate-containing blanks, a subsample (200 $\mathrm{mg}$ ) of each forage species was transferred to a 150 $\mathrm{mL}$ Wheaton bottle, which served as the fermentation flask. Rumen fluid was filtered through cheesecloth to contain large particulate matter followed by glass wool to filter out small particulate matter while continuously mixing with $\mathrm{CO}_{2}$ to maintain an anaerobic environment. A total of $14 \mathrm{~mL}$ of $\mathrm{pH}$-stabilized (6.8-6.9), $\mathrm{CO}_{2-}$ ventilated, phosphate-bicarbonate medium (Goering and Van Soest, 1970) and $2 \mathrm{~mL}$ of boiled distilled water were added to the incubation flask containing the plant

Table 2. Substrate quality constituents ${ }^{1}$ ( $\%$, DM basis)

\begin{tabular}{|c|c|c|c|c|c|c|c|}
\hline Substrate $^{2}$ & $\mathrm{CT}$ & $\mathrm{NDF}$ & $\mathrm{ADF}$ & Lignin & Crude fat & FOM & $\mathrm{N}$ \\
\hline CRN:ALF & 0 & 23.6 & 24.4 & 5.3 & 2.8 & 78.1 & 1.94 \\
\hline PTC 15 & 3.0 & 22.0 & 19.3 & 4.9 & 3.2 & 78.5 & 1.93 \\
\hline PTC 30 & 6.0 & 20.5 & 14.2 & 4.6 & 3.6 & 79.0 & 1.93 \\
\hline PTC 45 & 9.0 & 18.9 & 9.2 & 4.2 & 4.0 & 79.5 & 1.92 \\
\hline SL 15 & 0.9 & 23.3 & 20.5 & 5.3 & 2.9 & 78.3 & 1.95 \\
\hline SL 30 & 1.8 & 23.0 & 16.6 & 5.4 & 3.1 & 78.5 & 1.97 \\
\hline SL 45 & 2.6 & 22.7 & 12.8 & 5.5 & 3.3 & 78.8 & 1.99 \\
\hline
\end{tabular}


material. Flasks were sealed with greased butyl rubber stoppers and crimp sealed. A 4-mL subsample of mixed rumen fluid was injected into each sealed flask and incubated in each of 2 fermentation chambers once they reached a temperature of $39^{\circ} \mathrm{C}$. Pressure sensors were attached to each flask and the pressure within each flask was returned to zero by puncturing with a needle. Pressure readings were made automatically each $5 \mathrm{~min}$ for a 48 -h period. Pressure data were recorded using Pico Technology software (Eaton Socon, UK). After 48 $\mathrm{h}$ of fermentation, incubation flasks were removed from the fermentation chamber and placed in an ice bath to halt any further gas production. Upon completion of the 48-h fermentation, individual gas samples, a mixture of the gases produced during the 48-h fermentation, were taken from the headspace of individual fermentation flasks using a $10-\mathrm{mL}$ gas-tight syringe. Methane gas measurements were made by gas chromatography (Gow Mac Instrument Co., Bethlehem, PA) using a 5\% $\mathrm{CH}_{4}$ standard.

\section{Statistical Analyses}

We analyzed the data using PROC GLIMMIX of SAS (ver. 9.3; SAS Institute Inc., Cary, NC). The general linear model for the dependent variables $\mathrm{CH}_{4}$ and total gas production was a randomized complete block design with 7 treatments. There were 2 separate fermentation chambers which were run 2 different times, resulting in 4 blocks (replications). Each block contained 7 treatments in which 1 of the treatments was a control and the other 6 treatments were arranged as a 2 by 3 factorial (2 legumes and 3 concentrations; 15, 30, and $45 \%$ of PTC or SL, PTC-15, PTC-30, PTC-45, SL-15, SL-30, and SL-45, respectively). Each treatment within each block was assigned to 2 fermentation bottles (sampling unit), which were averaged (experimental unit). The statistical model was

$$
Y_{i j}=\mu+T_{i}+b_{j}+e_{i j}
$$

where $\mu$ is the overall mean, $T_{i}$ is the $i$ th treatment fixed effect $(\mathrm{n}=7), b_{j}$ is the $j$ th blocking random effect $(\mathrm{n}=4)$, and $e_{i j}$ is the independent and identically, normally distributed random error. The error term is the interaction between treatment and block factors.

One degree of freedom orthogonal polynomial contrast was performed to test for linear, quadratic, and equability of linear and quadratic effects between legumes. Least squares means were estimated and were tested using Fisher's least significant difference $(P \leq$ $0.05)$.

\section{RESULTS AND DISCUSSION}

Using SL in agricultural systems may require special management practices due to the possibility of invasiveness (USDA NRCS, 2006). Sericea lespedeza is an introduced plant species that occurs in the humid and subhumid regions of North America. It is listed as a noxious weed in Kansas and Colorado, which by law requires annual control to the extent that plant stands are prevented from producing seed. If promoted as forage, however, plant material is likely to be harvested before seed production due to assumed effects of maturity on nutritive value. Panicled-tick clover is a native species that occurs naturally in the humid and subhumid regions of North America. The overall goal of this experiment was to determine the effects of replacing alfalfa in a corn-alfalfa-based diet with forage legumes containing CT (SL or PTC). Substrates were isonitrogenous (19.5 $\mathrm{g}$ of $\mathrm{N} / \mathrm{kg}$ of $\mathrm{DM})$ and contained various amounts of $\mathrm{CT}$ depending on the amount of CT-containing forage replacing alfalfa. Physicochemical factors of dairy cattle diets have a direct effect on diet quality, DMI, and, subsequently, ME intake (Allen, 2000). The plant secondary metabolite component of the physicochemical composition has been shown to positively affect ME intake through mitigation of $\mathrm{CH}_{4}$ production (Bodas et al., 2012).

Quality constituents of experimental substrates are shown in Table 2. We observed an increase in substrate quality with increasing levels of alfalfa replacement by warm-season perennial legumes. The replacement of alfalfa with PTC resulted in a decrease in NDF as compared with CRN:ALF, ranging from a $6.7 \%$ decrease for PTC-15 to a $19.9 \%$ decrease for PTC-45. The addition of SL resulted in a decrease in NDF ranging from 1.3 to $3.8 \%$. We observed a similar trend relative to ADF. The replacement of alfalfa with PTC reduced ADF by $20.9 \%$ for PTC- 15 and $62.3 \%$ for PTC- 45 . Alfalfa replacement with SL reduced ADF by $16 \%$ and $47.5 \%$ for SL-15 and SL-45, respectively. Replacement of alfalfa with warm-season perennial legumes increased FOM of all diets. However, FOM was not affected to the same degree as NDF and ADF. When we replaced alfalfa with PTC, we observed an increase in FOM by as much as $1.8 \%$ at the $45 \%$ replacement level, whereas FOM of SL-45 was increased by less than $1 \%$ as compared with CRN:ALF. Overall, the replacement of alfalfa with PTC increased substrate nutritive value to a greater extent than replacement with SL. Condensed tannin concentration in the substrate increased with increasing replacement of alfalfa with each of the warm-season perennial legumes.

The physicochemical constituents of diets affect the dynamics of ruminal fermentation (Tedeschi et 


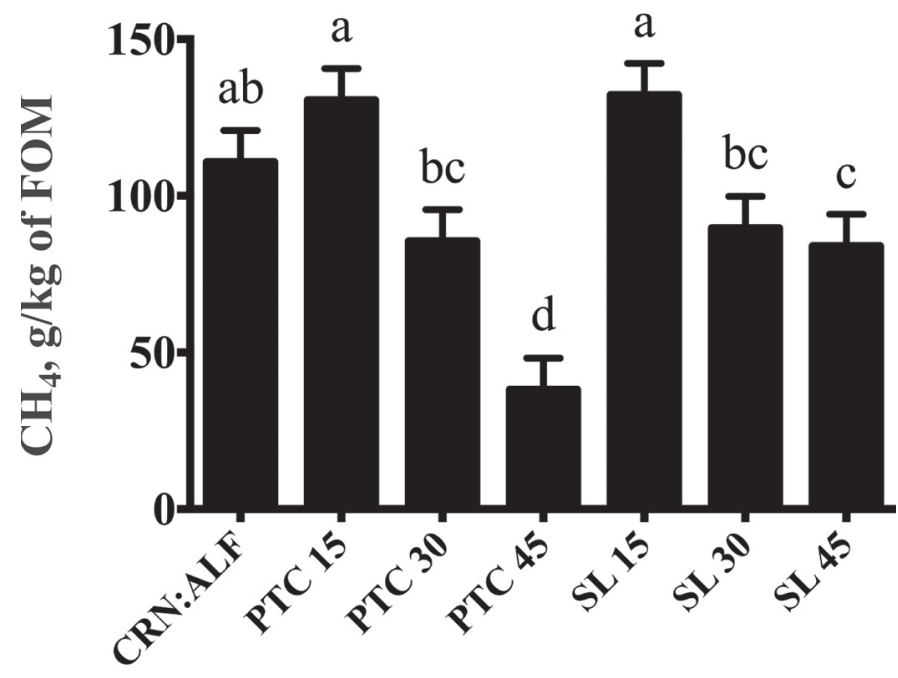

Treatment

Figure 1. Effect of replacing alfalfa with panicled-tick clover (PTC) or sericea lespedeza (SL) in a corn-alfalfa (CRN:ALF)-based dairy substrate on ruminal $\mathrm{CH}_{4}$ production. PTC or SL 15, 30, $45=$ percent replacement $(15,30$, or $45 \%)$ of the alfalfa component of the substrate with either PTC or SL; FOM = fermentable organic matter. Least squares means with the same letter $(\mathrm{a}-\mathrm{c})$ are not different $(P \leq$ $0.05) ; \mathrm{SEM}=10.1$.

al., 2009). There were no correlations between any physicochemical constituent of the substrates and $\mathrm{CH}_{4}$ production. It is not likely that any one constituent is solely responsible for the decrease in $\mathrm{CH}_{4}$. Rather, a combination of factors associated with the inclusion of PTC and SL contributed to the $\mathrm{CH}_{4}$ produced during in vitro fermentation. We speculate that the $\mathrm{CT}$ in these forages was a major contributing factor.

The in vitro $\mathrm{CH}_{4}$ production resulting from fermentation of experimental substrates is shown in Figure 1. The test of orthogonal polynomial contrast indicated that $\mathrm{CH}_{4}$ production decreased linearly $(P<0.0001)$ as alfalfa was replaced with PTC and SL. We observed no difference $(P>0.10)$ in $\mathrm{CH}_{4}$ production among PTC-15, SL-15, and CRN:ALF (130.5, 132.2, and110.8 $\mathrm{g} / \mathrm{kg}$ of FOM, respectively), despite ADF values that differed by as much as $5.1 \%$. Fermentation of PTC30 and SL-30 produced 85.5 and $89.7 \mathrm{~g}$ of $\mathrm{CH}_{4} / \mathrm{kg}$ of FOM, respectively, which also did not differ $(P>0.06)$ from the CRN:ALF control despite differences in ADF values ranging from 7.8 to 10.2. However, fermentation of PTC-45 resulted in the least amount of $\mathrm{CH}_{4}$ produced $(38.1 \mathrm{~g} / \mathrm{kg}$ of FOM), which was $54 \%$ less than that of SL-45 $(84.0 \mathrm{~g} / \mathrm{kg}$ of FOM; $P=0.002)$ and $65 \%$ less than that of CRN:ALF $(P<0.0001)$. The ADF for PTC-45 and SL-45 treatments differed from the control by 62 and $48 \%$, respectively, which could have contributed to the reduction in $\mathrm{CH}_{4}$ production. We should also mention that despite the lack of correlation between crude fat and $\mathrm{CH}_{4}$, the PTC-45 treatment had the greatest concentration of crude fat, which could have also contributed to a reduction in $\mathrm{CH}_{4}$. Inclusion of dietary fat in cattle diets has been reported to be a viable method for mitigation of enteric $\mathrm{CH}_{4}$ (Grainger and Beauchemin, 2011). Total gas production (L/kg of FOM) by fermentation of experimental substrates containing CT did not differ $(P=0.24)$ from that of the CRN:ALF control (Figure 2).

Plant secondary metabolites, namely $\mathrm{CT}$, have been shown to reduce enteric $\mathrm{CH}_{4}$ production by ruminants (Patra and Saxena, 2010; Puchala et al., 2012). However, apparent differences in $\mathrm{CT}$ from different plant sources have an effect on the degree with which ruminal $\mathrm{CH}_{4}$ production is affected. In our study, PTC-45 and SL-45 effectively reduced ruminal $\mathrm{CH}_{4}$ production and had CT concentrations of 8.7 and $2.3 \%$, respectively. The PTC- 45 treatment resulted in a $65.6 \%$ reduction in $\mathrm{CH}_{4}$, whereas that of the SL- 45 treatment was $24.2 \%$. Neither treatment resulted in a decrease in total gas production compared with CRN:ALF, suggesting that overall digestibility was not negatively affected by the presence of CT. The PTC-15 treatment had 3.0\% CT, similar to that of SL-45. However, the PTC-15 treatment was not effective at reducing ruminal $\mathrm{CH}_{4}$ production. We speculate that $\mathrm{CT}$ produced by SL are more biologically active (antimethanogenic) than $\mathrm{CT}$

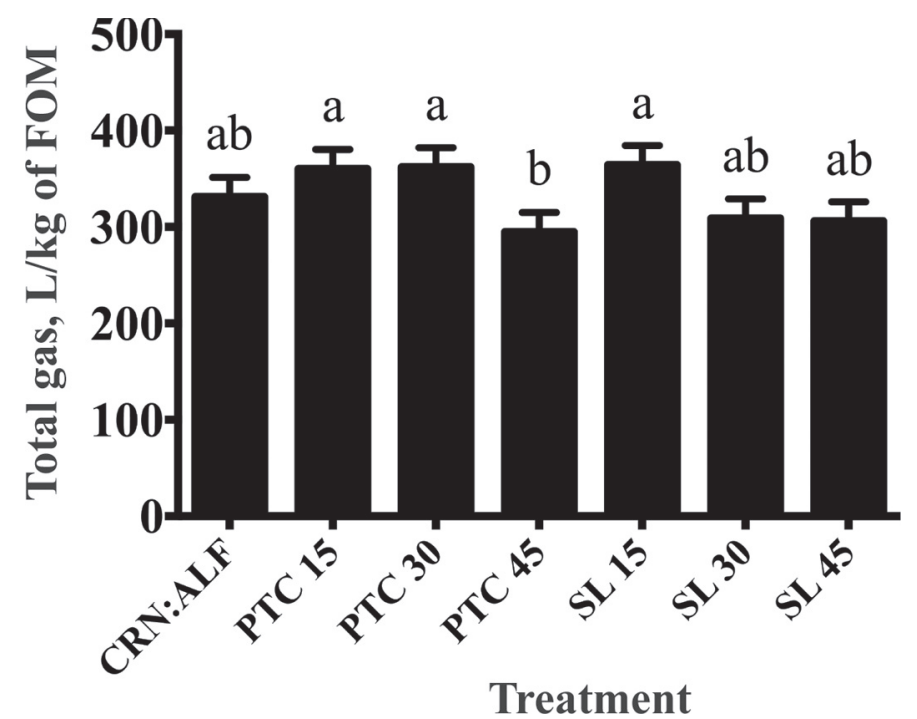

Figure 2. Effect of replacing alfalfa with panicled-tick clover (PTC) or sericea lespedeza (SL) in a corn-alfalfa (CRN:ALF)-based dairy substrate on ruminal total gas production. PTC or SL 15, 30, 45 $=$ percent replacement $(15,30$, or $45 \%)$ of the alfalfa component of the substrate with either PTC or LS; FOM = fermentable organic matter. Least squares means with the same letter $(\mathrm{a}, \mathrm{b})$ are not different $(\mathrm{P} \leq$ $0.05)$. SEM $=22.6$. 
produced by PTC, based on results reported by Naumann et al. (2014) in which CT from SL demonstrated greater than 4 times more biological activity (proteinbinding ability) than CT from PTC. In their study, CT from SL had a protein bound-to-protein precipitable phenolic ratio of 1.36 as compared with 0.32 for that of PTC.

Condensed tannin concentration, rather than molecular characteristics of $\mathrm{CT}$, is a common measure in $\mathrm{CT}-\mathrm{CH}_{4}$ mitigation studies. However, when comparing across plant species, it is apparent that $\mathrm{CT}$ concentration has little, if any value in predicting the effects of $\mathrm{CT}$ on ruminal $\mathrm{CH}_{4}$ production. Greater birdsfoot trefoil (Lotus pedunculatus) with $9.9 \%$ CT decreased ruminal $\mathrm{CH}_{4}$ production by as much as $42 \%$ compared with alfalfa, a non-CT-producing forage legume (Tavendale et al., 2005). Tan et al. (2011) measured the effects of leadtree (Leucaena leucocephala) CT at dietary concentrations ranging from 2 to $6 \%$. At $6 \% \mathrm{CT}$, ruminal $\mathrm{CH}_{4}$ and total gas were reduced by 63 and $42 \%$, respectively, almost $4 \%$ less CT and a 20\% greater reduction in $\mathrm{CH}_{4}$ than that reported by Tavendale et al. (2005). Naumann et al. (2013) evaluated the effects of several warm-season perennial legumes containing $\mathrm{CT}$ on $\mathrm{CH}_{4}$ and total gas production in vitro. In their study, the forage species were fermented alone without inclusion of any other dietary substrates in an effort to screen plants for their ability to reduce $\mathrm{CH}_{4}$ production. The $\mathrm{CH}_{4}$ reductions observed were unrealistic, as animals would not likely consume these forages alone, without inclusion of any other dietary substrates. Of the species surveyed, Illinois bundleflower (Desmanthus illinoensis), tall bushclover (Lespedeza stuevei), powderpuff (Mimosa strigillosa), and yellow puff (Neptunia lutea) had $\mathrm{CT}$ concentrations of $8,12,12$, and $8 \%$, respectively. These 4 species reduced ruminal $\mathrm{CH}_{4}$ by $34.8,87.2$, 80.1 , and $48.4 \%$, respectively, with no reduction in total gas production compared with a legume containing no CT, rhizoma perennial peanut (Arachis glabrata). The PTC and SL evaluated by Naumann et al. (2013) had CT concentrations of 12 and $8 \%$, respectively, and both reduced $\mathrm{CH}_{4}$ and total gas production. Relative to total gas production, the PTC-45 (9\% CT) and SL-45 (2.6\% CT) treatments evaluated in our study had no effect on total gas, which may be the result of fermentation of these forages with corn and alfalfa as opposed to just forage alone. The PTC-45 treatment in our study had a CT concentration similar to that of the Illinois bundleflower and yellow puff reported by Naumann et al. (2013). However, we observed a reduction in ruminal $\mathrm{CH}_{4}$ production by the PTC- 45 treatment of 1.8 and 1.4 times more than Illinois bundleflower and yellow puff, respectively. We observed a decrease in $\mathrm{CH}_{4}$ mitigation by PTC- 45 relative to the PTC fermented alone by Naumann et al. (2013). In that study, $\mathrm{CH}_{4}$ was reduced by $79 \%$ and total gas was reduced by $28 \%$ as compared with rhizoma perennial peanut, a forage containing no CT. For $\mathrm{CH}_{4}$ reduction, the efficacy of PTC-45 was $16 \%$ less than that of PTC alone. Despite a reduction in efficacy, the addition of PTC to a simulated dairy diet containing substrates of corn grain and alfalfa reduced $\mathrm{CH}_{4}$ production by $66 \%$ and did not negatively affect total gas production in vitro.

Sericea lespedeza also reduces $\mathrm{CH}_{4}$ when fed to ruminants in in vivo studies. Puchala et al. (2005) reported that goats grazing on SL pasture produced $57 \%$ less $\mathrm{CH}_{4}$ than goats grazing a mixture of crabgrass and tall fescue. This level of efficacy is similar to that of SL reported on by Naumann et al. (2013), which resulted in a $60 \%$ reduction in vitro. Those authors speculated that decreases in $\mathrm{CH}_{4}$ emissions by goats were due to the greater concentration of CT from SL as compared with crabgrass-tall fescue. Animut et al. (2008b) also reported reductions in $\mathrm{CH}_{4}$ emissions by goats consuming SL alone or SL mixed with annual lespedeza (Lespedeza striata) and quebracho (Schinopsis spp.), both CT-containing plant species. Polyethylene glycol was used in Animut et al. (2008b) to inhibit activity of CT and results suggested $\mathrm{CT}$ to be a major factor contributing to $\mathrm{CH}_{4}$ reduction. Puchala et al. (2012) fed SL to goats as either fresh forage or hay and reported a decrease in $\mathrm{CH}_{4}$ emissions of $37 \%$ for fresh forage and $40 \%$ for hay as compared with alfalfa. Polyethylene glycol treatment used in Puchala et al. (2012) indicated that $\mathrm{CT}$ from SL was primarily responsible for $\mathrm{CH}_{4}$ mitigation. Reporting the ability of SL to inhibit ruminal $\mathrm{CH}_{4}$ production is not novel. However, previous studies have focused on the use of SL as forage or feed for small ruminants (sheep and goats) either by itself or as part of forage-based diets. Others have neglected to address the question of whether or not SL will reduce $\mathrm{CH}_{4}$ when incorporated into a dairy cow-type diet that contains a concentrate fraction such as corn. We observed a decrease in $\mathrm{CH}_{4}$ mitigation by SL-45 as compared with the SL fermented alone by Naumann et al. (2013). In their study, $\mathrm{CH}_{4}$ was reduced by $60 \%$ and total gas was reduced by $25 \%$ as compared with rhizoma perennial peanut. The ability of SL-45 to reduce $\mathrm{CH}_{4}$ decreased by $60 \%$ compared with that of SL alone was reported in their previous study. The SL-45 was not as effective at reducing $\mathrm{CH}_{4}$ as compared with the sericea lespedeza pasture reported on by Puchala et al. (2005) or sericea lespedeza fresh forage or hay reported on by Puchala et al. (2012). Although less effective as compared with previous reports, the addition of SL to a simulated dairy diet containing substrates of corn grain 
and alfalfa reduced $\mathrm{CH}_{4}$ production by $24 \%$ and had no negative effect on total gas production in vitro.

Our analysis indicated that ratio of procyanidin to prodelphinidin of PTC and SL were 60:40 and 0:100, respectively. The structure of $\mathrm{CT}$ relative to anthocyanidin composition may be a critical factor in the role of CT bioactivity (Hagerman et al., 1998; Soares et al., 2007; Hagerman, 2012). Anthocyanidins differ in the hydroxylation pattern of the B-ring constituent of the proanthocyanidin. For example, the anthocyanidins propelargonidin, procyanidin, and prodelphinidin possess 1, 2, and 3 B-ring hydroxyl groups, respectively. It is possible that the greater number of hydroxyls present, the greater the biological activity of the CT. This is because hydroxyl groups serve as substitution groups or binding sites for macromolecules, such as protein, carbohydrates, lipids, and minerals. If this characteristic is a determining factor in biological activity $\left(\mathrm{CH}_{4}\right.$ mitigation $)$, then the smaller the procyanidinto-prodelphinidin ratio in $\mathrm{CT}$ composition, the greater the biological activity of the CT. Given the reports by (Naumann et al., 2014) that biological activity of CT from SL was greater than biological activity of CT from PTC, we speculated that CT composed primarily of prodelphinidin has greater antimethanogenic properties. Considering the observed procyanidin-toprodelphinidin ratios of SL and PTC in our study, the theory that hydroxylation pattern is a contributing factor to $\mathrm{CH}_{4}$ mitigation seems plausible. However, more data from a wider range of $\mathrm{CT}$ containing species is needed to draw a conclusion relating procyanidin-toprodelphinidin ratio to biological activity of CT.

\section{CONCLUSIONS}

Results from our study suggest that replacement of alfalfa with $45 \%$ of PTC or SL in corn-alfalfa-based substrates will suppress ruminal $\mathrm{CH}_{4}$ with no compromise in total gas production (i.e., FOM) in vitro. We speculate that CT present in the PTC and SL are in large part responsible for the $\mathrm{CH}_{4}$ reduction observed. However, the only way to know for sure would be to include purified CT from these forages in in vitro fermentations. Further evaluations of the experimental substrates using whole forages as opposed to only leaf material in in situ or in vivo animal systems would be required before adoption for commercial application. If proven effective in vivo, replacement of commonly fed non-CT-containing legumes, such as alfalfa, with CT-containing legumes might be a viable method to decrease the effect of animal agriculture on greenhouse gas production.

\section{REFERENCES}

Allen, M. S. 2000. Effects of diet on short-term regulation of feed intake by lactating dairy cattle. J. Dairy Sci. 83:1598-1624. http:// dx.doi.org/10.3168/jds.S0022-0302(00)75030-2.

Animut, G., R. Puchala, A. L. Goetsch, A. K. Patra, T. Sahlu, V. H. Varel, and J. Wells. 2008a. Methane emission by goats consuming diets with different levels of condensed tannins from lespedeza. Anim. Feed Sci. Technol. 144:212-227. http://dx.doi. org/10.1016/j.anifeedsci.2007.10.014.

Animut, G., R. Puchala, A. L. Goetsch, A. K. Patra, T. Sahlu, V. H. Varel, and J. Wells. 2008b. Methane emission by goats consuming different sources of condensed tannins. Anim. Feed Sci. Technol. 144:228-241. http://dx.doi.org/10.1016/j.anifeedsci.2007.10.015.

Asquith, T. N., and L. G. Butler. 1985. Use of dye-labeled protein as spectrophotometric assay for protein precipitants such as tannin. J. Chem. Ecol. 11:1535-1544. http://dx.doi.org/10.1007/ BF01012199.

Athanasiadou, S., I. Kyriazakis, F. Jackson, and R. L. Coop. 2001. Direct anthelmintic effects of condensed tannins towards different gastrointestinal nematodes of sheep: In vitro and in vivo studies. Vet. Parasitol. 99:205-219.

Bodas, R., N. Prieto, R. García-González, S. Andrés, F. J. Giráldez, and S. López. 2012. Manipulation of rumen fermentation and methane production with plant secondary metabolites. Anim. Feed Sci. Technol. 176:78-93. http://dx.doi.org/10.1016/j. anifeedsci.2012.07.010

Coblentz, W. K., and J. H. Grabber. 2013. In situ protein degradation of alfalfa and birdsfoot trefoil hays and silages as influenced by condensed tannin concentration. J. Dairy Sci. 96:3120-3137. http://dx.doi.org/10.3168/jds.2012-6098.

FASS. 2010. Guide for the Care and Use of Agricultural Animals in Research and Teaching. 3rd ed. Federation of Animal Science Societies, Champaign, IL.

Goel, G., and H. P. S. Makkar. 2012. Methane mitigation from ruminants using tannins and saponins. Trop. Anim. Health Prod. 44:729-739. http://dx.doi.org/10.1007/s11250-011-9966-2.

Goering, H., and P. Van Soest. 1970. Forage fiber analysis: Apparatus, reagents, procedures, and some applications. Pages 1-20 in Agriculture Research Service Agriculture Handbook. USDA, Agricultural Research Service, Washington, DC.

Grainger, C., and K. A. Beauchemin. 2011. Can enteric methane emissions from ruminants be lowered without lowering their production? Anim. Feed Sci. Technol. 166-167:308-320. http://dx.doi. org/10.1016/j.anifeedsci.2011.04.021.

Grainger, C., T. Clarke, M. J. Auldist, K. A. Beauchemin, S. M. Mcginn, G. C. Waghorn, and R. J. Eckard. 2009. Potential use of Acacia mearnsii condensed tannins to reduce methane emissions and nitrogen excretion from grazing dairy cows. Can. J. Anim. Sci. 89:241-251.

Hagerman, A., M. Rice, and N. Ritchard. 1998. Mechanisms of protein precipitation for two tannins, pentagalloyl glucose and epicatechin (4-8) catechin (procyanidin). J. Agric. Food Chem. 46:2590-2595.

Hagerman, A. E. 2012. Fifty years of polyphenol-protein complexes. Pages 71-97 in Recent Advances in Polyphenol Research. V. Cheynier, P. Sarni-Manchado, and S. Quideau, ed. John Wiley \& Sons, Ltd., Oxford, UK.

Hagerman, A. E., and L. G. Butler. 1978. Protein precipitation method for the quantitative determination of tannins. J. Agric. Food Chem. 26:809-812.

Johnson, K. A., and D. E. Johnson. 1995. Methane emissions from cattle. J. Anim. Sci. 73:2483-2492.

Jones, W., and J. L. Mangan. 1977. Complexes of the condensed tannins of sainfoin (Onobrychis viciifolia Scop.) with fraction 1 leaf protein and with submaxillary mucoprotein, and their reversal by polyethylene glycol and pH. J. Sci. Food Agric. 28:126-136.

Li, C., R. Leverence, J. D. Trombley, S. Xu, J. Yang, Y. Tian, J. D. Reed, and A. E. Hagerman. 2010. High molecular weight persimmon (Diospyros kaki L.) proanthocyanidin: A highly galloylated, A-linked tannin with an unusual flavonol terminal unit, myricetin. 
J. Agric. Food Chem. 58:9033-9042. http://dx.doi.org/10.1021/ jf102552b.

Mehlich, A. 1984. Mehlich 3 soil test extractant: A modification of Mehlich 2 extractant. Comm. Soil Sci. Plant Anal. 15:1409-1416.

Naumann, H. D., A. E. Hagerman, B. D. Lambert, J. P. Muir, L. O. Tedeschi, and M. M. Kothmann. 2014. Molecular weight and protein-precipitating ability of condensed tannins from warmseason perennial legumes. J. Plant Interact. 9:212-219. http:// dx.doi.org/10.1080/17429145.2013.811547.

Naumann, H. D., L. O. Tedeschi, J. P. Muir, B. D. Lambert, and M. M. Kothmann. 2013. Effect of molecular weight of condensed tannins from warm-season perennial legumes on ruminal methane production in vitro. Biochem. Syst. Ecol. 50:154-162.

Patra, A. K. 2012. Enteric methane mitigation technologies for ruminant livestock: A synthesis of current research and future directions. Environ. Monit. Assess. 184:1929-1952. http://dx.doi. org/10.1007/s10661-011-2090-y.

Patra, A. K., and J. Saxena. 2010. A new perspective on the use of plant secondary metabolites to inhibit methanogenesis in the rumen. Phytochemistry 71:1198-1222. http://dx.doi.org/10.1016/j. phytochem.2010.05.010.

Puchala, R., G. Animut, A. K. Patra, G. D. Detweiler, J. E. Wells, V. H. Varel, and T. Sahlu. 2012. Effects of different fresh-cut forages and their hays on feed intake, digestibility, heat production, and ruminal methane emission by Boer $\times$ Spanish goats 1 . J. Anim. Sci. 90:2754-2762. http://dx.doi.org/10.2527/jas.2011-4879.

Puchala, R., B. Min, A. Goetsch, and T. Sahlu. 2005. The effect of a condensed tannin-containing forage on methane emission by goats. J. Anim. Sci. 83:182-186.

Schofield, P., D. M. Mbugua, and A. N. Pell. 2001. Analysis of condensed tannins: A review. Anim. Feed Sci. Technol. 91:21-40.
Soares, S., N. Mateus, and V. Freitas. 2007. Interaction of different polyphenols with bovine serum albumin (BSA) and human salivary alpha-amylase (HSA) by fluorescence quenching. J. Agric. Food Chem. 55:6726-6735. http://dx.doi.org/10.1021/jf070905x.

Strumeyer, D. H., and M. J. Malin. 1975. Condensed tannins in grain sorghum: isolation, fractionation, and characterization. J. Agric. Food Chem. 23:909-914.

Tan, H. Y., C. C. Sieo, N. Abdullah, J. B. Liang, X. D. Huang, and Y. W. Ho. 2011. Effects of condensed tannins from Leucaena on methane production, rumen fermentation and populations of methanogens and protozoa in vitro. Anim. Feed Sci. Technol. 169:185-193. http://dx.doi.org/10.1016/j.anifeedsci.2011.07.004.

Tavendale, M. H., L. P. Meagher, D. Pacheco, N. Walker, G. T. Attwood, and S. Sivakumaran. 2005. Methane production from in vitro rumen incubations with Lotus pedunculatus and Medicago sativa, and effects of extractable condensed tannin fractions on methanogenesis. Anim. Feed Sci. Technol. 123-124:403-419. http://dx.doi.org/10.1016/j.anifeedsci.2005.04.037.

Tedeschi, L. O., P. J. Kononoff, K. Karges, and M. L. Gibson. 2009. Effects of chemical composition variation on the dynamics of ruminal fermentation and biological value of corn milling (co) products. J. Dairy Sci. 92:401-413. http://dx.doi.org/10.3168/jds.2008-1141.

USDA Natural Resources Conservation Service (NRCS). 2006. Plant Fact Sheet Chinese Lespedeza. 2. USDA NRCS, Washington, DC.

Yokota, K., H. Kimura, S. Ogawa, and T. Akihiro. 2013. Analysis of A-type and B-type highly polymeric proanthocyanidins and their biological activities as nutraceuticals. J. Chem. 2013: 352042 http://dx.doi.org/10.1155/2013/352042. 